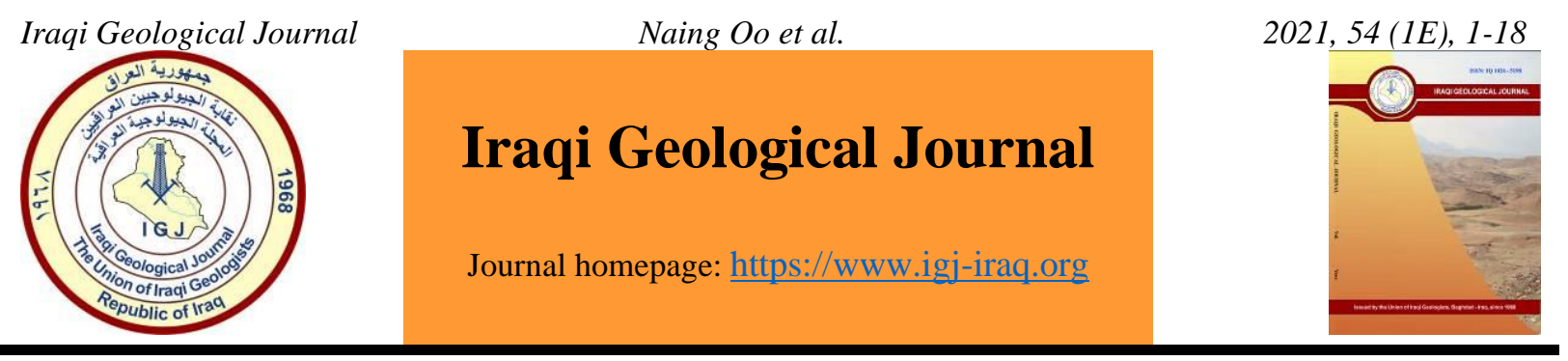

\title{
Origin of the Kyaukmyet Low-Sulfidation Epithermal Gold Prospect, Monywa District, Central Myanmar
}

\author{
Toe Naing Oo ${ }^{* 1,2}$, Agung Harijoko ${ }^{1}$ and Lucas Donny Setijadji ${ }^{1}$ \\ ${ }^{1}$ Department of Geological Engineering, Faculty of Engineering, Gadjah Mada University, Yogyakarta, Indonesia \\ ${ }^{2}$ Department of Geology, Dagon University, Yangon, Myanmar \\ *Correspondence: toenaingoo.geo184@gmail.com
}

Received: 12 January 2021; Accepted: 10 March 2021; Published: 31 May 2021

\begin{abstract}
The Kyaukmyet prospect is one of the principal epithermal gold prospects in the Monywa District, Central Myanmar; its gold- and base metal-bearing quartz veins contain around $3 \mathrm{~g} / \mathrm{t}$ gold. Ore minerals are mainly hosted by volcanic and volcaniclastic rocks of the Late Oligocene to Middle Miocene Magyigon Formation. The distribution of magmatic intrusions in the area is controlled by ENE-WSW trending faults; these faults are likely related to ore mineralization. Common ore minerals at the Kyaukmyet prospect include pyrite, sphalerite, galena, chalcopyrite, and electrum. They occur in mineralized crustiform-textured brecciated quartz veins and banded (colloform) and massive quartz veins. Mineralized rock is accompanied by silicification and propylitic and argillic alterations. The alteration mineral assemblages include quartz, adularia, calcite, chlorite, illite/smectite, sericite, and illite. Fluid inclusions in the quartz veins have homogenization temperatures ranging from $148{ }^{\circ} \mathrm{C}$ to $304{ }^{\circ} \mathrm{C}$ and salinities from $0.35 \mathrm{wt} \%$ to $2.75 \mathrm{wt} \% \mathrm{NaCl}$ equiv. The quartz in the mineralized quartz veins was most likely precipitated at a depth ranges $165-256 \mathrm{~m}$ below the paleosurface. The precipitation of gold at the Kyaukmyet prospect may have been formed by mixing large amounts of meteoric fluid with small amounts of magmatic fluid. The coexistence of liquid-rich and vapor-rich inclusions and presence of adularia and bladed calcite indicate that fluid boiling is caused the main mechanism of ore formation. The vein textures, ore mineral assemblages, alteration minerals and fluid inclusion data suggest that the Kyaukmyet prospect is a polymetallic low-sulfidation epithermal gold deposit.
\end{abstract}

Keywords: Gold-base metals mineralization; Hydrothermal fluid; Kyaukmyet prospect; Quartz veins; Fluid inclusions

\section{Introduction}

The Monywa District is an important copper-gold district in Myanmar (Zaw, 2017; Zaw et al. 2017) and the district lies within the N-S trending Inner Volcanic Magmatic Arc (Zaw, 1989; Zaw, 1990; Chhibber, 1934) which is an important metallogenic province in Myanmar Fig.1. Geographically, the Monywa District is located at the west of the Chindwin River and Monywa City in Central Myanmar Figs.1 and 2. There are four well-known, very large high-sulfidation copper-gold ore deposits in the Monywa District: the Sebataung, Sebetaung South, Kyisintaung, and Letpadaung deposits Fig.2. The district also hosts low-sulfidation style $\mathrm{Au}-\mathrm{Ag}$ mineralized prospects in the outcrops of hypabyssal

DOI: 10.46717/igj.54.1E.1Ms-2021-05-22 
rhyolite porphyry. Ore minerals at these prospects are mainly hosted by a series of andesite porphyry intrusions and extrusions and by a suite of mixed rhyolitic volcanic rocks that composed of the Magyigon Formation. Zircon geochronologic dating shows that the basement rocks of the Monywa District are Cretaceous in age. Oligocene rhyolitic volcanics formed at 27-24 Ma and host low-sulfidation mineralized rock and a Miocene andesite porphyry at Letpadaung with an emplacement age of $19 \mathrm{Ma}$ (Knight and Zaw, 2015) has been associated by a high-sulfidation mineralizing event. The Kyaukmyet prospect is approximately $5 \mathrm{~km} \mathrm{NE}$ of the high-sulfidation Kyisintaung copper-gold deposit. Personnel from the company operating the Kyisintaung mine have recorded the occurrence of Au-Ag and base metal minerals at Kyaukmyet. In the Kyaukmyet prospect area, exploration has been conducted by detailed geologic and geophysical investigations. The host rocks the Kyaukmyet prospect are members of the Late Oligocene to Middle Miocene aged Magyigon Formation consisting of volcanic and volcaniclastic rocks Fig.2 (Mitchell et al. 2011). The gold-mineralized rhyolites in the research area were first described by Chhibber (1934). Veins trend nearly ENE-WSW; their orientation is similar to the regional structural trends in the area. Vein textures and minor adularia documented by Kirwin (1994) (unpublished data) suggests a low-sulfidation epithermal system.

Previous exploration data suggest that the maximum gold grade discovered after a $6000 \mathrm{~m}$ diamond drilling program was around 3 to $7 \mathrm{~g} / \mathrm{t}$. The gold-mineralized rocks also contain zinc (up to $234 \mathrm{ppm}$ ), lead (256 ppm), copper (112 ppm) antimony (up to $569 \mathrm{ppm}$ ), and arsenic (up to $6370 \mathrm{ppm}$ ) (Htet, 2008) (unpublished data). However, most of the previous research works merely give rough description of individual mineral deposits, or the relationship between volcanic rocks and regional gold mineralization in the Kyaukmyet prospect area, Monywa District (Knight and Zaw, 2015; Mitchell et al., 2011; Kirwin, 1994; Htet, 2008). Therefore, many significant research works are still required for the characterization and verification of epithermal mineralization and associated with hydrothermal alteration in the Kyaukmyet prospect area in terms of geologic setting, related to volcanic rocks, alteration mineralogy, ore and gangue mineralogy, characteristics of hydrothermal fluids, paragenetic sequences of mineralization, control on the ore mineralization and formation, and origin and evolution of hydrothermal system. This study aims to document the geology, alteration, mineralization, and hydrothermal fluid evolution of the Kyaukmyet prospect to determine the ore deposition mechanisms. In this paper, we focus on a detailed description and characteristics of the gold-base metal veins and mineralized rocks including alteration minerals, ore mineral assemblages and paragenesis, together with fluid inclusion petrography and microthermometry to constrain the evolution of the ore-forming fluids and the depth of ore formation.

\section{Regional Geologic Setting}

Myanmar is divided into two tectonic provinces by the $1500 \mathrm{~km}$ long N-S trending Sagaing Fault (Zaw 1989; 1990; 2017) Fig.1. The eastern part of the country is the Sibumasu terrane; it encompasses the Shan Plateau, the Mogok-Mandalay-Mergui Belt (MMMB), and the Shan Scarps. The western part is the West Burma terrane comprising the Indo-Myanmar Ranges and the Inner Volcanic Magmatic Arc (also called the Central Volcanic Belt) (Mitchell et al. 2012) Fig.1. The Inner Volcanic Magmatic Arc is a N-S trending magmatic and metallogenic belt and located between the Western Inner Myanmar Tertiary Basin and the Eastern Inner Myanmar Tertiary Basin. It extends from Mt. Loamy and the jade mines in the far north of Myanmar to the Gulf of Martaban in the south and beyond to the islands of west of Sumatra, Indonesia Fig.1. The Inner Volcanic Magmatic Arc is composed of Late Cretaceous to Tertiary granodioritic intrusive rocks with a subordinate sequence of Late Cretaceous to Quaternary volcanic rocks (Zaw, 1990; 2017). 


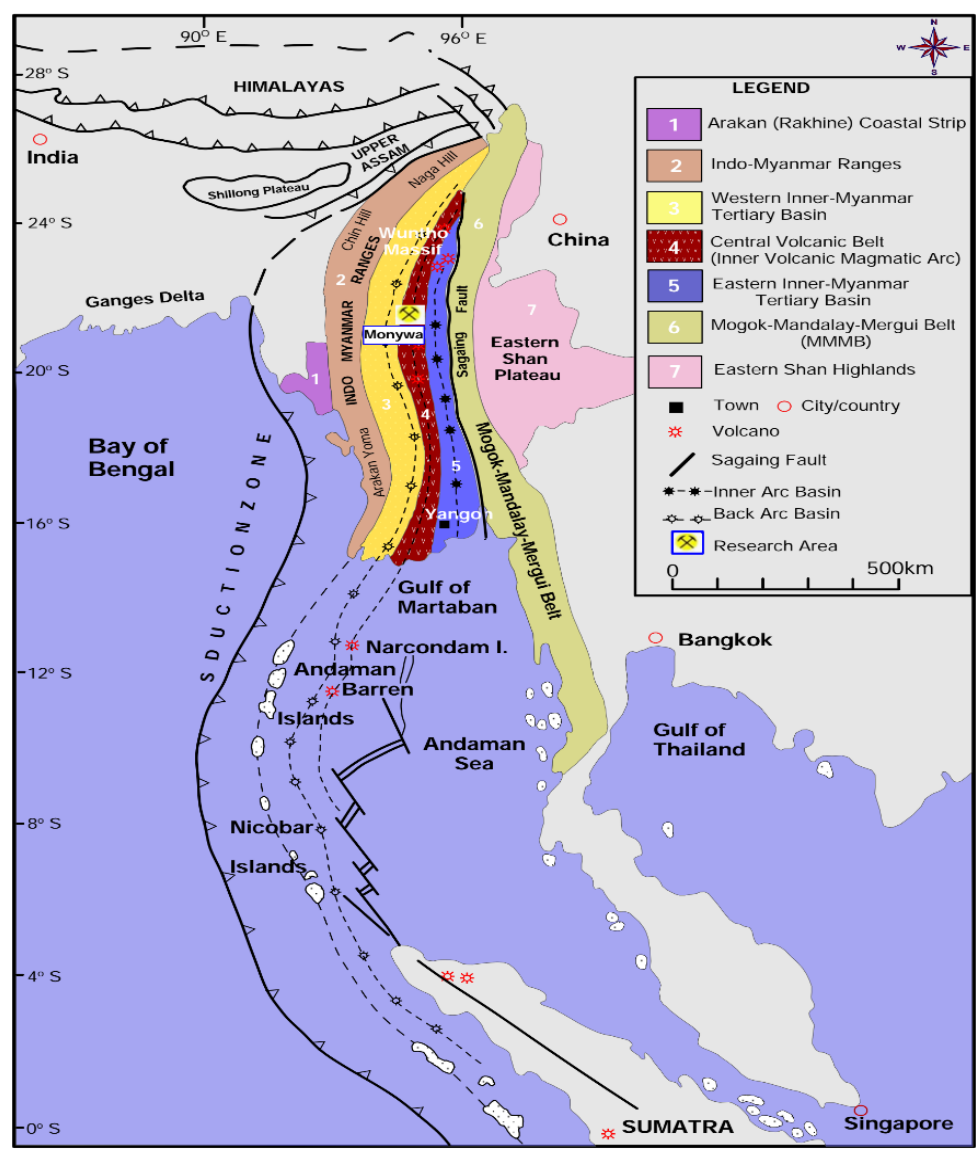

Fig.1. General tectonic setting of Myanmar (modified from Zaw, 1989; 1990; 2017). Study area is located within the Monywa District within the Central Volcanic Belt (Inner Volcanic Magmatic Arc)

The Monywa District is located in the Inner Volcanic Magmatic Arc within the Central Volcanic Belt (Win, 1998; Mitchell et al., 2011; Zaw, 2017). The district has attracted the attention of geologists because of its great potential for economic $\mathrm{Cu}$ and $\mathrm{Au}$ deposits. In this district, metallic ores are found as both high-sulfidation epithermal-type $\mathrm{Cu}$ and low-sulfidation epithermal-type $\mathrm{Au}$ deposits. Before mining, the district's resources amounted to approximately $2 \times 10^{9}$ tons of ore containing more than $7 \times$ $10^{7}$ tons of $\mathrm{Cu}$ metal making Monywa the second largest $\mathrm{Cu}$ deposit in SE Asia (Mitchell et al. 2011; Zaw et al. 2017). The Monywa copper deposits and nearby gold-silver prospects (including Kyaukmyet) lie at a few kilometers east of a cluster of small inliers of basement rocks and granitic intrusions that coincide with a regional aeromagnetic anomaly on a geanticlinal axis (Kirwin, 1994). The basement rocks are overlain locally by volcanic rocks and both are overlain unconformably by eastward-dipping, probably Eocene, quartzofeldspathic sandstones with a prominent west-facing scarp slope at Powintaung. Most of the metallic deposits between Powintaung and the Chindwin River are hosted by the Magyigon Formation and porphyritic intrusions Fig.2.

The Magyigon Formation is part of the Oligocene to Miocene Pegu Group. The Pegu Group is widespread in upper Myanmar occupying the cores of synclines in the Western Trough and forming ranges of low hills between the Chindwin River and Sagaing Fault which lies about $100 \mathrm{~km}$ to the east. The Magyigon Formation consists dominantly of marine sandstones and shales, but blocky rhyolitic pyroclastic flows and rhyolite lavas and tuffs can be found interbedded with the sandstone at some localities. Rhyolite domes and dykes are probably also present (Mitchell et al. 2011). In the Monywa District the Magyigon succession shows tight irregular upright folds possibly reflecting structural incompetence. Fold axes within the Magyigon Formation at the southwest part of the copper- gold 
district mostly trend northeasterly and the epithermal vein systems follow a similar trend. Andesitic volcaniclastic rocks are found in some of the hills at Kyisintaung and Letpadaung. Regional correlations suggest that these andesitic volcaniclastics underlie the Late Oligocene to Middle Miocene rhyolites in the Magyigon Formation.

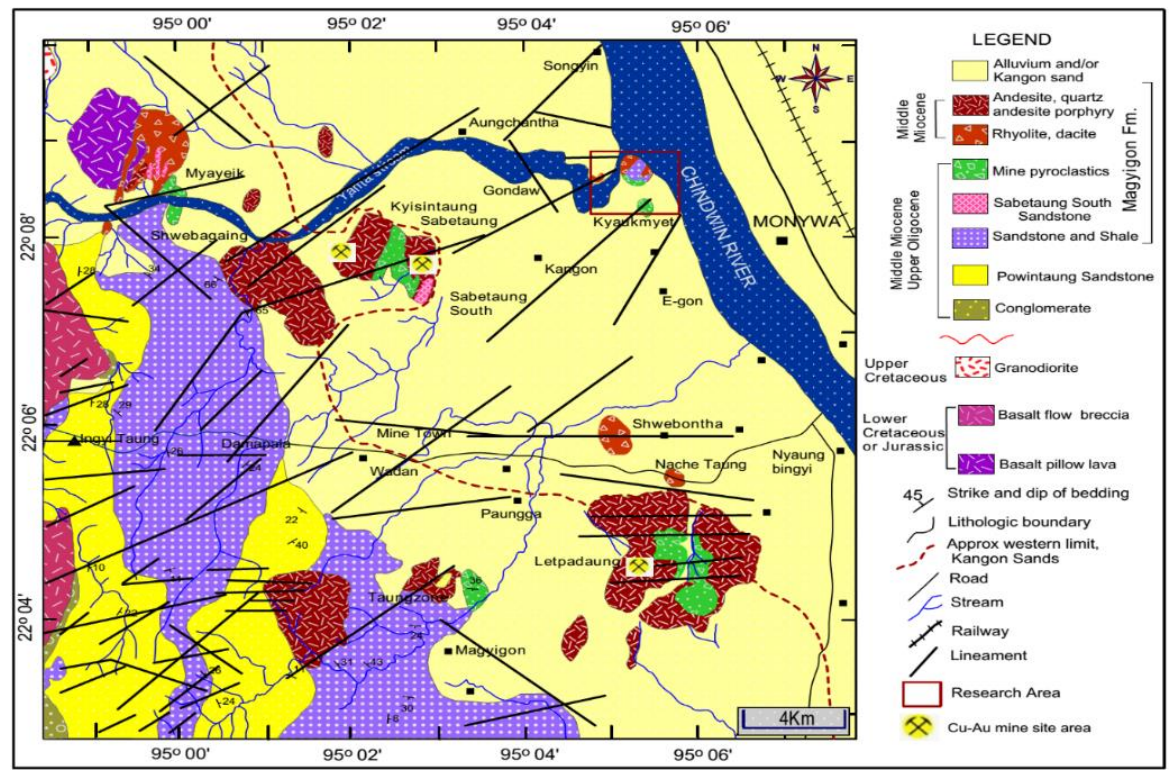

Fig. 2. Regional geological map of Monywa copper-gold district, modified from (Mitchell et al. 2011)

\section{Materials and Methods}

This research was carried out by a field investigation followed by laboratory analysis of the samples collected. In the field, 41 samples were collected from the surface outcrops in the Kyaukmyet prospect area: hydrothermally altered rock (15 samples) and mineralized quartz vein (26 samples). Twenty samples were prepared for thin sections, doubly-polished thin sections, or polished sections. Thin sections and polished sections were examined petrographically to study primary and secondary (alteration) mineral assemblages. In a subsequent study, detailed ore microscopy of polished thin-sections using both transmitted and reflected light was conducted to observe ore mineral assemblages and textural relationships. Fluid inclusion analyses were performed on doubly-polished quartz wafers of varied thicknesses $(100-200 \mu \mathrm{m})$. Seven quartz vein samples were collected from sulfide-bearing mineralized zones. These samples were carefully selected for fluid inclusion study; the samples contained both metal-bearing minerals and clear quartz grains that were amenable to fluid inclusions study under the microscope. For the fluid inclusion investigation, preliminary petrographic studies were done for the selected samples and followed by microthermometric measurement. The types of fluid inclusions present were determined according to their shape, size, and the number of phases in each fluid inclusions and the inclusions were classified as primary or secondary according to the standard criteria described by (Roedder, 1984; Bodnar et al., 1985). In total, 132 fluid inclusions were measured to obtain microthermometric data including homogenization and final ice-melting temperatures. The final ice-melting temperatures were measured at a heating rate of less than $0.1{ }^{\circ} \mathrm{C} / \mathrm{min}$ and the homogenization temperatures at a rate of $\leq 1{ }^{\circ} \mathrm{C} / \mathrm{min}$ respectively. Salinity was calculated from the Tm using the equation of freezing temperature depression of Bodnar (1993). The fluid inclusion studies and microthermometric measurements were performed using a Linkam TH600 heating/freezing stage with a temperature range of -196 to $+600{ }^{\circ} \mathrm{C}$. The stage was connected to a Nikon petrographic microscope and employed Axiovision imaging software. Temperature reproducibility was $\pm 0.1{ }^{\circ} \mathrm{C}$ for 
microthermometric determination. All laboratory analyses were carried out at the Department of Earth Resources Engineering, Kyushu University, Fukuoka, Japan.

\section{Results}

\subsection{Geology of the Kyaukmyet Area}

The Kyaukmyet area is predominantly covered by sedimentary, volcanic, and volcaniclastic rocks of the Late Oligocene to Middle Miocene Magyigon Formation. Physiographically, the Kyaukmyet area is located at the confluence of two large rivers, the Yama Stream and the Chindwin River. Maximum elevation in the area is $150 \mathrm{~m}$ above sea level, $70 \mathrm{~m}$ above the surrounding floodplain. The lithologies in the research area are a sedimentary succession consisting of cherty or siliceous mudstone, siltstone, and quartzofeldspathic sandstone and volcaniclastic and volcanic units of tuffaceous rocks, lapilli tuff, and rhyolite Fig.3. Stratigraphically, silicified sandstone, mudstone, and siltstone are the oldest rock units. These units are well exposed in the western and central parts of the research area. The silicified sandstone, mudstone, and siltstone unit is unconformably underlain by the rhyolitic volcanic, the predominant rock unit in the research area. Geological structures in the research area are dominantly in an ENE-WSW direction. This structural trend might be controlled by the movement along the Chindwin and Monastery faults. It has been speculated that these northeast-trending structures would have experienced dextral movement similar to the movement on the well-studied Sagaing Fault (Zaw, 1989; Zaw, 1990). These strike slip faults were probably the main geologic control on the gold and base metal mineralization in the area. Our field observations indicate that gold and base metals ore in the form of crustiform textured gold-bearing brecciated quartz veins (KMV-007) and banded (colloform) (KMV-004) and massive quartz veins (KMV-008) were in most cases associated with silicification and argillic alteration. Propylitic alteration occurred at the periphery of individual mineralized zones. Photographs taken in the field of mineralized host rocks at the Kyaukmyet prospect are shown in Fig.4.

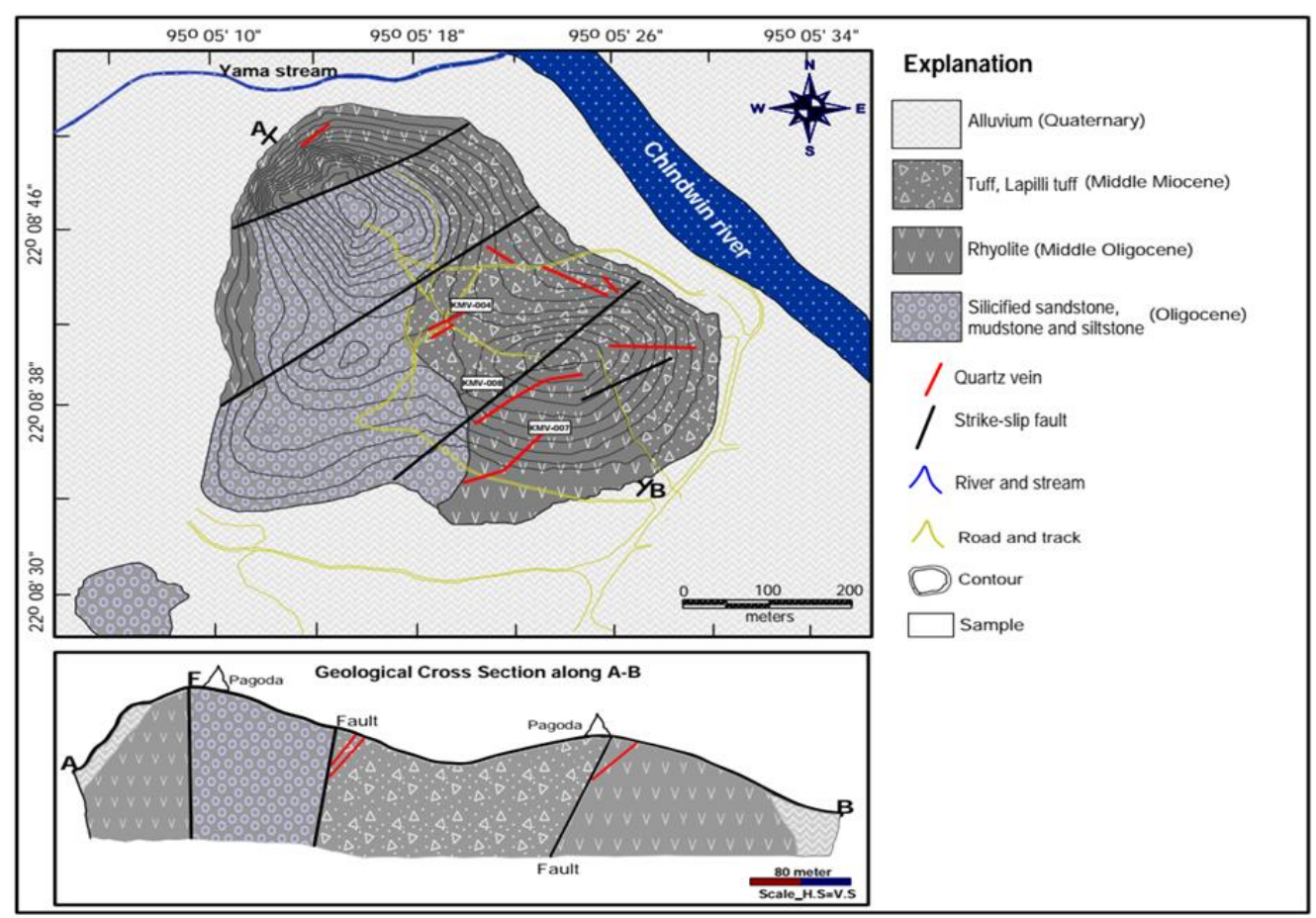

Fig.3. Geological map of the Kyaukmyet prospect area, Monywa District, Central Myanmar and cross section along A-B (modified from Htet, 2008). 

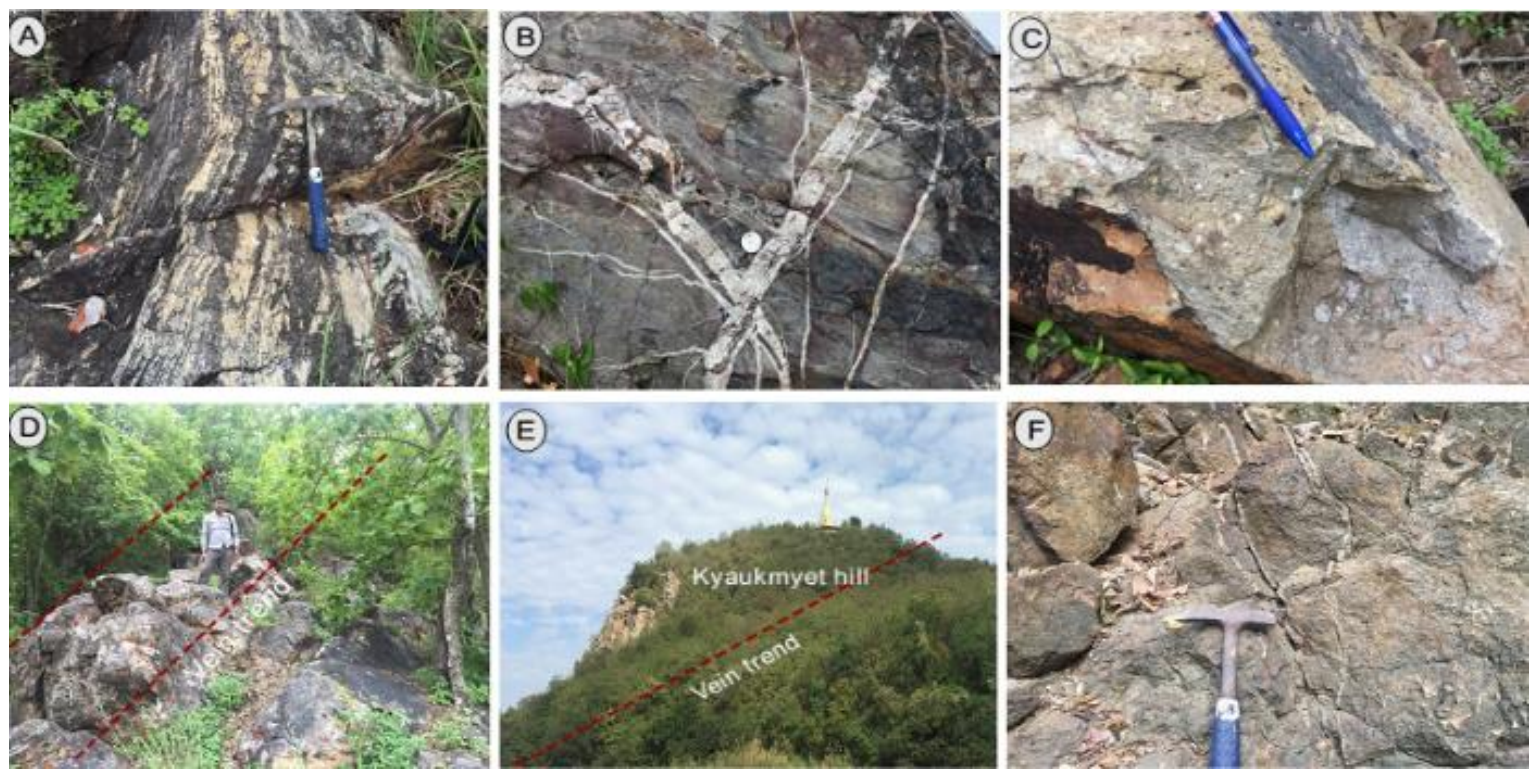

Fig.4. Representative field photographs of different rock types in the Kyaukmyet prospect; (a) flow banding outcrop nature of rhyolite; (b) comb quartz and multi quartz veinlet (stockwork vein) in rhyolite rock unit; (c) lapilli tuff unit showing ash white to light reddish color in fresh surface due to alteration effects; (d-e) fault running as a mineralization ENE-WSW trending direction; (f) silicified sandstone, siltstone and mudstone unit

\subsection{Host Rock Hydrothermal Alteration}

The volcanic and volcaniclastic rocks at the Kyaukmyet prospect that surround the mineralized veins are extensively altered. The mineral assemblages show that the types of alteration include silicification as well as argillic and propylitic alteration. Silicification and argillic alteration are the main types of alteration around the mineralized zones and propylitic alteration has taken place around some quartz veins. Considered on a larger scale, the propylitic zone is peripheral to the mineralized system. Mineralized quartz veins are abundant in the silicified zone but the groundmass in this zone is also strongly silicified. There are a variety of textures in the quartz carbonate \pm adularia veins. These veins commonly show gold-bearing brecciated quartz with massive, banded, lattice bladed, colloform, colloform-crustiform, comb, zonal, or cockade textures. Silicified host rock displays equigranular microcrystalline quartz with bands of sulfide minerals (pyrite) Fig.5. Under the microscope, minor amounts of adularia can be seen intergrown with quartz and lattice-bladed calcite as open-space fillings. This calcite appears as light-colored rhombs with irregular extinction under crossed nicols Fig.5. It occurs as idiomorphic clustered crystals intergrown with quartz. The argillic alteration zones are proximal to major mineralized quartz veins and these zones are characterized by the presence of quartz, illite, illite/smectite, sericite, and pyrite. These zones are intimately associated with quartz, minor amounts of pyrite, and the replacement of plagioclase by illite, sericite, and illite/smectite, Fig.5. Pyrite is found as dissemination and in some cases as veinlets within the argillically-altered rock. Propylitic alteration zones are the outermost alteration zones. Propylitic alteration is recorded in the phenocrysts and groundmass of the rhyolite host rock and the lapilli tuff units. The main alteration minerals in these zones are quartz, chlorite, and pyrite; these minerals generally replace the plagioclase phenocrysts Fig.5. 

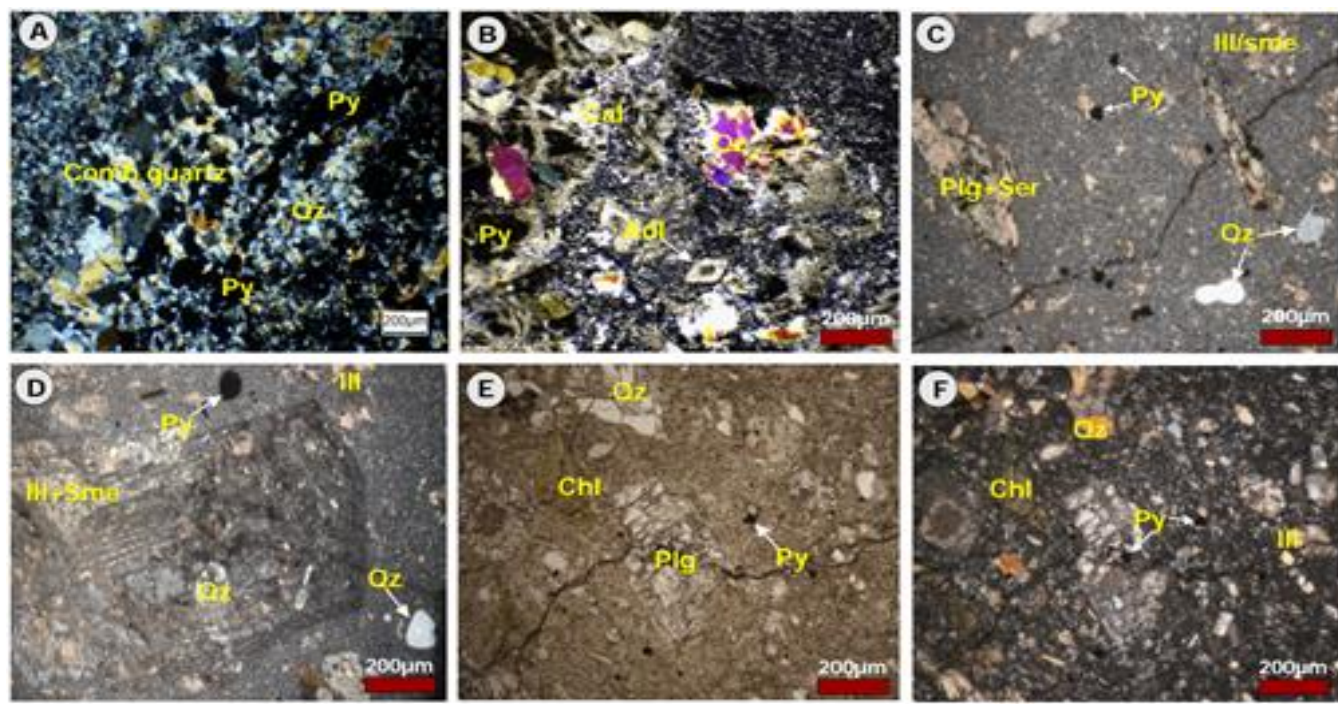

Fig.5. Photomicrographs showing alteration minerals at the Kyaukmyet prospect; (a) quartz-pyrite veinlet and comb-textured quartz crystals within silicic alteration; (b) adularia is found as intergrowth with quartz and lattice-bladed calcite replaced quartz in open space filling, (c-d) alteration of plagioclase to illite/smectite, sericite and illite, small amount of quartz and pyrite; (e-f) chlorite, pyrite, illite and quartz replacement in plagioclase phenocryst in volcanic and volcaniclastic host rock. Abbreviations: Py-pyrite; Adl-adularia; Chl-chlorite; Ser-sericite; Ill-illite; Sme-smectite; Qz-quartz; Cal-calcite; Opq-opaque; Plg-plagioclase

\subsection{Mineralized Veins}

In the research area, most of the gold and base-metals mineralization are hosted by the volcanic and volcaniclastic rock units of the Magyigon Formation. Most of the ore minerals are in open-space filling veins with lesser amounts of replacement and disseminated ore minerals in the rhyolite host rock. In general, the mineralized vein is identified into three major textures such as gold- and base metal-bearing crustiform (KMV-007), banded (colloform) (KMV-004), or massive quartz veins (KMV-008) respectively. These veins generally trend ENE-WSW and they are mostly found in the southeastern and central part of the research area. Crustiform textured gold-bearing brecciated quartz veins (KMV-007) are observed around the main veins, in zones of argillically altered wall rock, and in oxidized zones Fig.6. Banded (colloform) (KMV-004) texture is a characteristic feature of quartz-chalcedonic aggregates in fine rhythmic and repetitive bands Fig.6. This texture is characterized mainly by light gray to whitish quartz, thin layers of dark-colored bands of sulfide minerals. Massive quartz veins (KMV-008) are dominantly composed of crystalline quartz with minor calcite and are associated with sulfide minerals; they show typical open-space filling ore textures Fig.6. The contacts between the mineralized veins and the host rocks are sharp suggesting that they are most likely open space filling veins. In addition, a number of different vein quartz textures are observed in mineralized veins including massive, banded, and crustiform quartz, comb quartz, lattice bladed calcite and lattice-bladed calcite replaced by quartz. Zonal, mosaic, cockade, and plumose/feathery textures are also present locally Fig.6 and 7. Some quartz bands include minor amounts of adularia with its typical rhombic shape. Comb quartz occurs as parallel or subparallel euhedral quartz crystals oriented perpendicular to the vein walls. This texture is typically formed by open space filling from hydrothermal fluids that were slightly supersaturated with respect to silica. In some places colloform, zonal, comb, and cockade textures are also found in fluid boiling zones. 

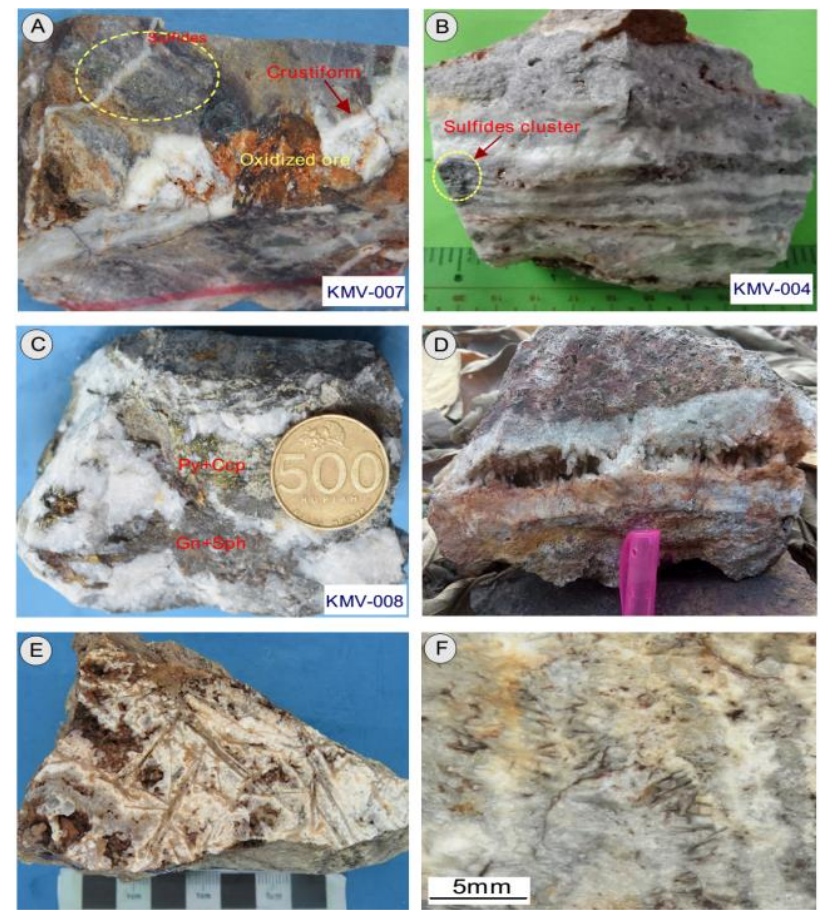

Fig.6. Photographs showing various epithermal quartz veins texture from the Kyaukmyet prospect; (a) crustiform textured gold-bearing brecciated and oxidized quartz vein; (b) banded (colloform) quartz vein with mineralization band; (c) massive quartz vein with sulfides cluster; (d) elongated euhedral quartz crystal showing parallel or subparallel crystals oriented perpendicular to the vein wall; (e) lattice-bladed calcite replaced by quartz; (f) lattice bladed calcite
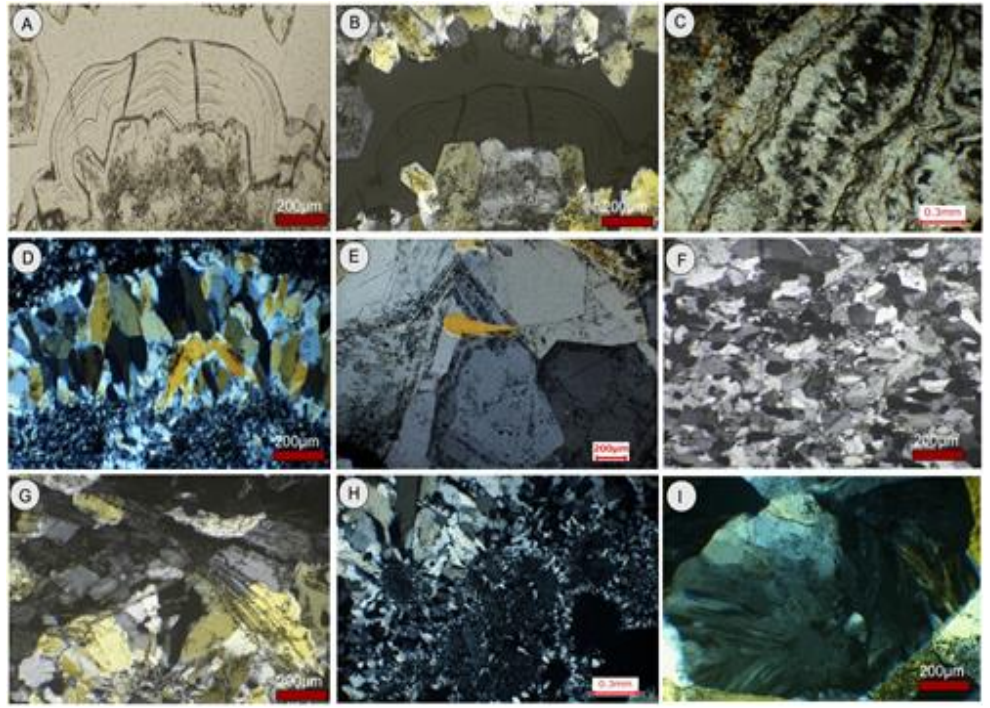

Fig.7. Photomicrographs of mineral textures from the Kyaukmyet prospect; ( $a$ and b) colloform texture under plane polar light and crossed polar light; (c) crustiform quartz texture with mineralized pyrite bands under plane polar light; (d) "teeth-like" comb quartz growing from opposite sides of the vein wall and interlocking in the center under crossed polar light; (e) zonal quartz texture in euhedral quartz crystals; (f) mosaic or jigsaw texture with crystalline quartz grains; (g) lattice bladed quartz texture under crossed polar light; (h) cockade quartz texture under crossed polar light; (i) plumose/feathery quartz texture under crossed polar light 


\subsection{Ore and Alteration Mineralogy}

The most common primary ore minerals in the mineralized veins at the Kyaukmyet prospect include pyrite, galena, sphalerite, chalcopyrite, and electrum. The predominant alteration minerals are pyrite, quartz, adularia, sericite, and minor amounts of calcite. Covellite, goethite, and hematite occur as late supergene minerals in the shallower portions of the veins. The ore minerals occur as replacements, disseminations, and massive accumulations in the mineralized veins. Pyrite was deposited during the entire mineralization event as both primary sulfide and alteration mineral. Pyrite is the most commonly observed sulfide and most of the pyrite are euhedral and some grains are replaced by galena and/or sphalerite and/or chalcopyrite. In some cases, pyrite is replaced by goethite and hematite that retains the pyrite's original colloform texture Fig.8. Some pyrite crystals also exhibit a ribbon-like texture. Galena is one of the more abundant sulfide minerals in the Kyaukmyet prospect veins. It is generally associated with sphalerite, replaces pyrite and sphalerite, and is in turn replaced by sphalerite. The galena is light gray in color in reflected light and typically shows triangular pits under the microscope. The rims of galena crystals are commonly replaced by pyrite and sphalerite Fig.8. Sphalerite is also a common ore mineral at Kyaukmyet and it occurs as subhedral to anhedral grains or in irregular shapes and it displays internal reflections. Under the microscope, sphalerite has a gray color and contains blebs of chalcopyrite commonly described as chalcopyrite disease (Awadh et al. 2008; Awadh and Nejbert, 2016). Sphalerite is mostly associated with pyrite, galena, and chalcopyrite. It is observed as a replacement mineral in large euhedral grains of pyrite and replaces the rims of galena grains Fig.8. In some specimens, sphalerite-galena intergrowths have been observed Fig.8. Chalcopyrite is a minor mineral in this assemblage. Most of chalcopyrite grains are anhedral in shape and occur as fracture filling grains in quartz gangue or in fractures in larger euhedral grain in pyrite in the matrix Fig.8.

Gold occurs as a native gold or electrum grains in euhedral pyrite crystal and can only be observed under the microscope. Gold grains in euhedral pyrite grains are 1-2 $\mu \mathrm{m}$ in size Fig.8. Covellite is observed as a secondary replacement mineral and commonly in association with pyrite, sphalerite, and hematite as well as goethite. The covellite has its characteristic deep indigo-blue color commonly with a purple iridescence. It commonly rims or replaces pyrite within silica vugs but also occurs as massive aggregates and as fine-grained disseminated crystals Fig.8. Goethite commonly occurs as concentric rhythmic colloform bands Fig.8. This texture is a result of material being precipitated from a hot colloidal aqueous solution or gel (Salem et al. 2010). Under reflected light, hematite is white in color with high reflectivity; it occurs as irregular patches and laths. Two types of hematite can be identified in the research area: (1) primary hematite occurs as alternating rhythmic and concentric bands associated with goethite Fig.8, and (2) secondary hematite occurs as small euhedral equigranularity grains produced from the dehydration of goethite.

\subsection{Mineral Paragenesis}

Textural relationships among the ore and alteration minerals allow to establish the paragenetic sequence for the Kyaukmyet prospect area and can be divided into three main stages: the alteration, mineralization, and supergene stages Fig.9. The alteration stage is characterized by the presence of pyrite, quartz, illite, illite/smectite, sericite and chlorite. The mineralization stage can be further divided into main ore stage and post ore stage. Main ore stage is represented by silicic alteration that is intimately associated with the gold- and base metal-bearing quartz veins in the volcanic and volcaniclastic host rocks. This stage produced crustiform-textured gold-bearing brecciated quartz veins and banded (colloform) to massive quartz veins that contain different abundances of sulfide minerals (pyrite, galena, sphalerite, and chalcopyrite) and gold/electrum. The quartz veins are composed of fineto coarse-grained quartz crystals that are well developed along growth zones. Gold and base metal-bearing quartz veins typically show colloform, crustiform, massive, lattice bladed, cockade, and 
comb textures and vug infill textures. Post ore stage is represented by the formation of microcrystalline quartz and pyrite. Mineralization main ore stage and post ore stage are intimately associated with quartz, illite, illite/smectite, sericite and chlorite alteration. The supergene stage mineral assemblages consist of covellite, goethite, and hematite.
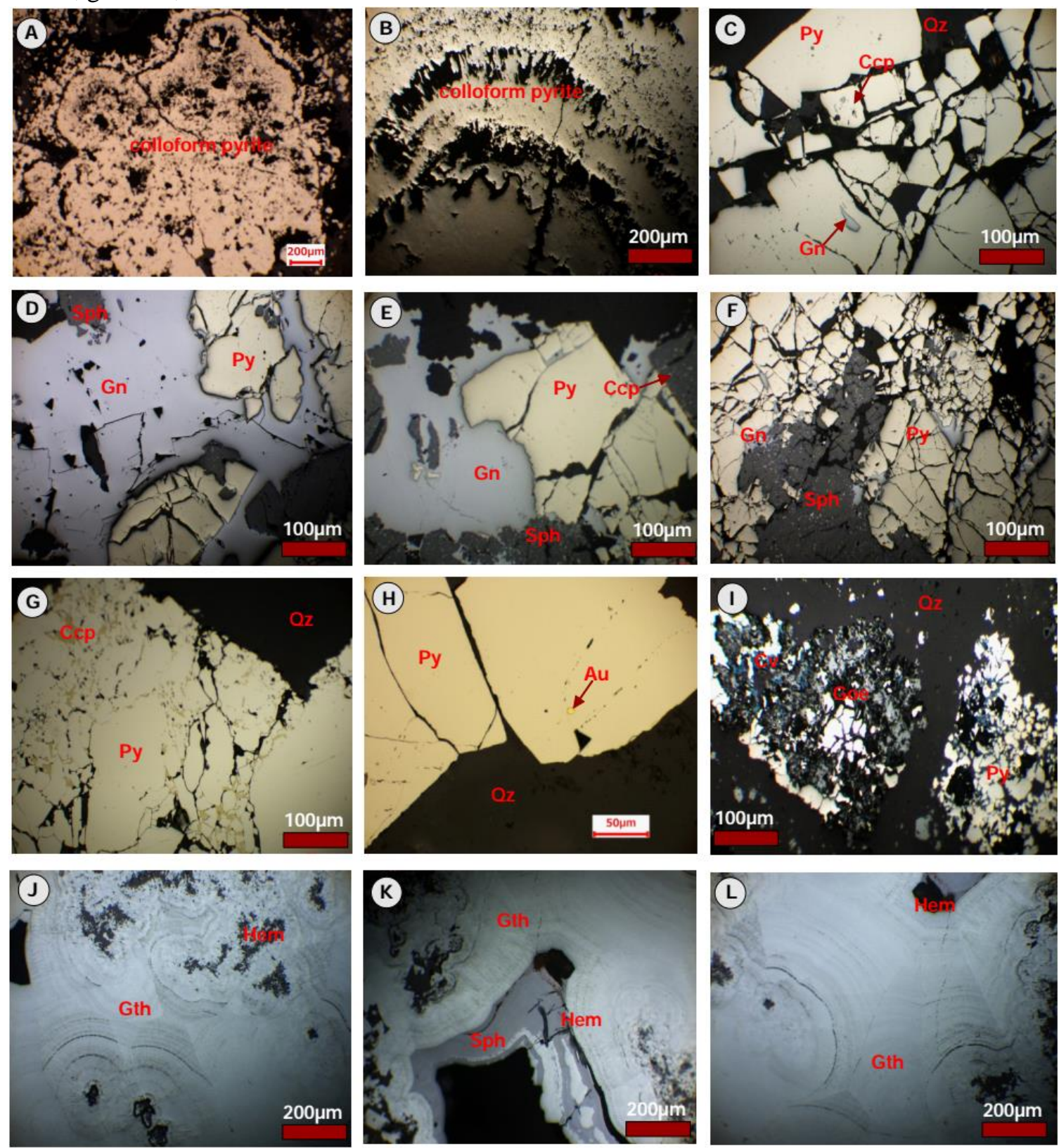

Fig.8. Photomicrographs showing characteristics of ore mineral assemblages in mineralized quartz veins from the Kyaukmyet prospect; (a-b) colloform texture pyrite; (c) euhedral pyrite crystal is replaced by galena and chalcopyrite; (d-e) galena (triangular pits) enclose earlier formed pyrite and sphalerite; (f) large crystal pyrite replaced by sphalerite and galena in crystal interior; (g) refilling of fracture in the deformed pyrite crystal by chalcopyrite in quartz; (h) small fine grained gold occurs as in the euhedral pyrite crystal; (i) covellite replacement pyrite within the vug of the silica alteration; (j) colloform-crustiform texture of goethite; (k) sphalerite and hematite infilling or replacing bands between goethite layers in colloform-crustiform textured; (1) concentric growth banding showing sequential development of hematite and goethite: Abbreviations: Py-pyrite; Gn-galena; Sph-sphalerite; Ccp-chalcopyite; Cv-covellite; Hem-hematite; Gth-goethite; Qz-quartz 


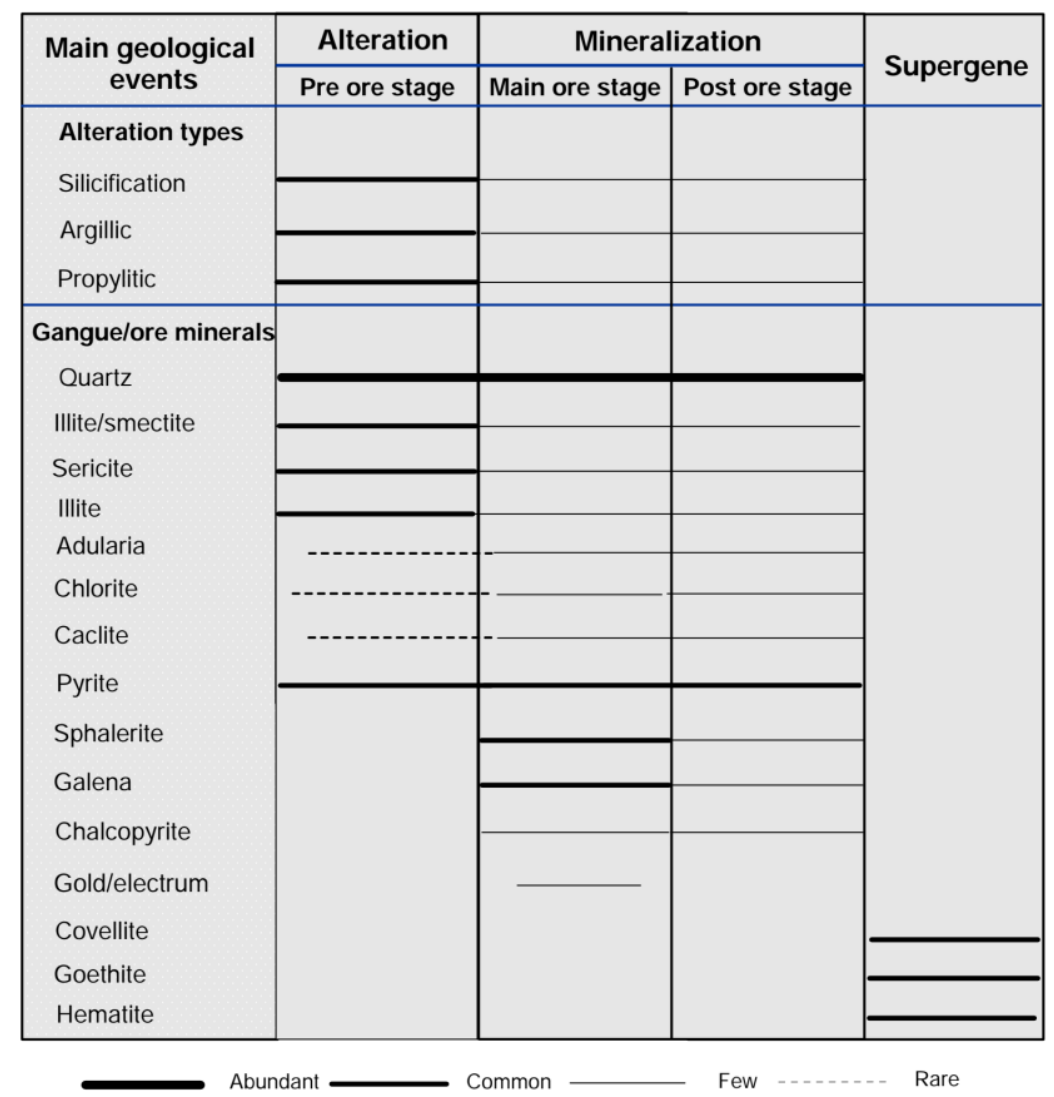

Fig.9. Generalized paragenetic scheme for the Kyaukmyet prospect

\subsection{Fluid Inclusion Study}

\subsubsection{Fluid inclusion petrography}

Mineralized quartz vein samples for fluid inclusion study were collected from three different goldand base metal-bearing quartz veins at the Kyaukmyet prospect: the KMV-004, KMV-007, and KMV-008 veins. Seven doubly-polished quartz wafers were prepared for petrographic analysis and three were samples of vein quartz suitable for fluid inclusion studies. A total of 132 fluid inclusion micro thermometric measurements were performed on primary fluid inclusions. These primary inclusions were generally included along the boundaries of growth zones or on isolated planes in a quartz crystal. At room temperature, most of the primary fluid inclusions were two-phase inclusions containing both a liquid and a vapor phase. The liquid:vapor ratios in the individual inclusions varied. Secondary fluid inclusions were also observed in quartz along healed fracture but no detailed microthermometric measurements were conducted on these inclusions.

The primary fluid inclusions have oval, spherical, rounded, elongated, irregular, or facetted shapes and they occur in cluster or within growth zones. They range from around $10 \mu \mathrm{m}$ to slightly over $50 \mu \mathrm{m}$ in size but most are $>10 \mu \mathrm{m}$ in diameter Fig.10. Following standard fluid inclusion nomenclature (Roedder, 1984; Shepherd et al.1985), there are two principal types of primary fluid inclusions: two-phase liquid-rich inclusions (Type I) and two-phase vapor-rich inclusions (Type II). In Type I inclusions, the vapor phase commonly occupies $10 \%-30 \%$ of the total volume of the inclusions. When heated, Type I inclusions homogenize to a liquid. Type II inclusions also contain a liquid phase and a vapor bubble but the vapor phase is typically $>75 \mathrm{vol} \%$ of the inclusion's volume and they also homogenized into liquid phase. Type II inclusions are found as isolated inclusions or coexisting with Type I inclusions. Type I fluid inclusions are considerably more abundant than Type II inclusions in all the samples examined. Type II inclusions are relatively rare and were only found in specific thin 
sections. However, there is abundant evidence that the liquid-rich Type I inclusions and the vapor-rich Type II inclusions coexisted, suggesting that that fluid boiling occurred during the mineralization stages.
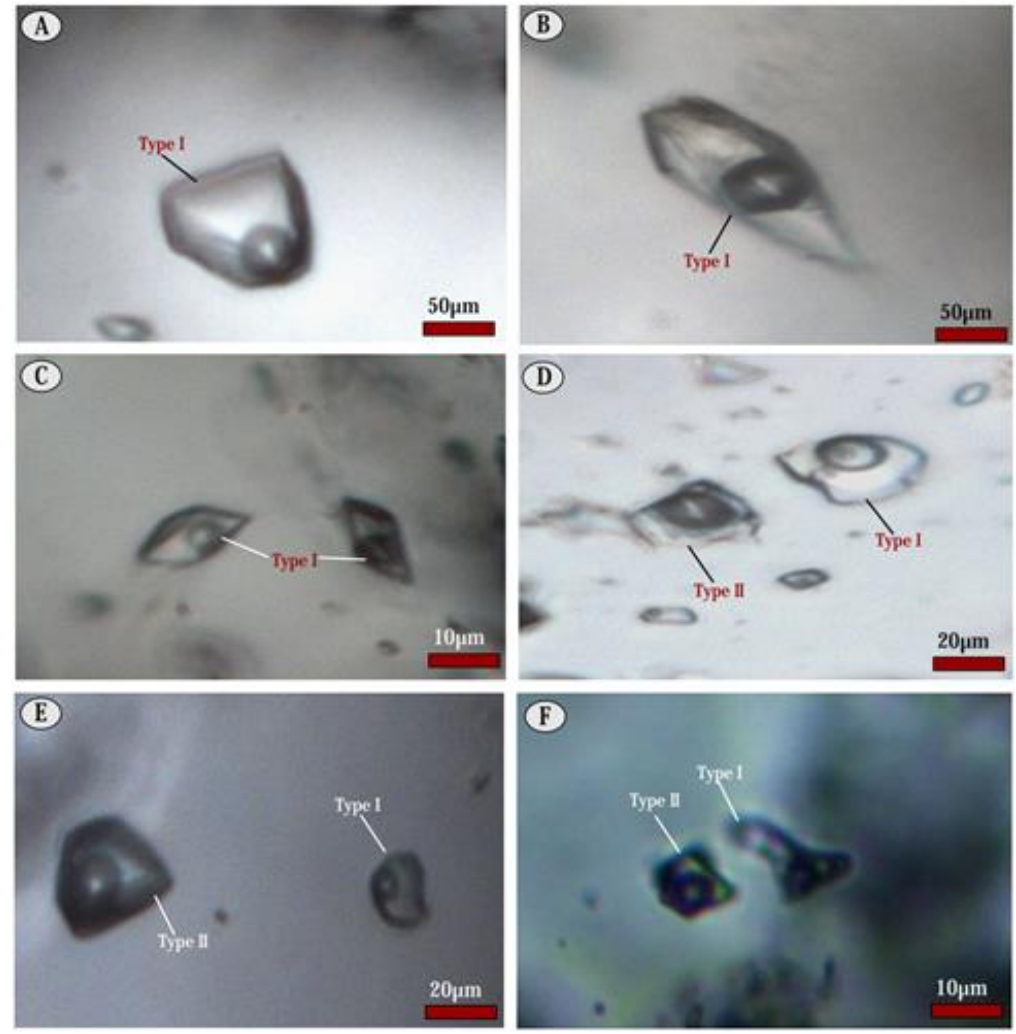

Fig.10. Photomicrographs of primary fluid inclusions in quartz from the Kyaukmyet prospect; (a-c) Two-phase liquid-rich inclusions; (d-f) Coexisting liquid-rich and vapor-rich two-phase inclusions

\subsubsection{Fluid inclusion microthermometry}

For this research, typical primary two-phase liquid-rich and vapor-rich fluid inclusions from different gold- and base metal-bearing quartz veins were chosen for microthermometric measurements. This study was designed to determine the temperature, salinity, pressure, density, and depth of the hydrothermal fluid. Fluid inclusion homogenization temperatures for 53 inclusions from crustiform textured gold-bearing brecciated quartz vein (KMV-007) ranged from $178{ }^{\circ} \mathrm{C}$ to $299{ }^{\circ} \mathrm{C}, 45$ inclusions from banded (colloform) quartz vein (KMV-008) showed $148-282^{\circ} \mathrm{C}$, and 34 inclusions from massive quartz vein (KMV-004) returned temperatures from $168{ }^{\circ} \mathrm{C}$ to $300{ }^{\circ} \mathrm{C}$. Histograms for these homogenization temperatures are shown in Fig.11. The peaks of these histograms show that the formation temperature of the Kyaukmyet quartz veins was between $200{ }^{\circ} \mathrm{C}$ and $220{ }^{\circ} \mathrm{C}$ for $\mathrm{KMV}-007$, $\mathrm{KMV}-004$ ranges between $200-240{ }^{\circ} \mathrm{C}$ and KMV-008 ranges between $180-200{ }^{\circ} \mathrm{C}$ respectively Fig. 11 . Average first ice-melting temperatures for the three veins were $-0.85{ }^{\circ} \mathrm{C}$ (KMV-007), $-0.70{ }^{\circ} \mathrm{C}$ (KMV-008), and $-0.85{ }^{\circ} \mathrm{C}$ (KMV-004). Using Bodnar's Equation (1993), the apparent salinities of the inclusion fluids were calculated from the fluid inclusion melting temperatures. The average salinities of the Kyaukmyet quartz vein fluids were $1.75 \mathrm{wt} \% \mathrm{NaCl}$ equiv. (KMV-007), $1.21 \mathrm{wt} \% \mathrm{NaCl}$ equiv. (KMV-008), and $1.55 \mathrm{wt} \% \mathrm{NaCl}$ equiv. (KMV-004). Histograms for the individual melting temperature/salinity determinations are also shown in Fig.11. The salinity and homogenization temperatures are used to estimate the prospect's formation temperature, trapping pressure, paleodepth, fluid evolution processes, and deposit type. 

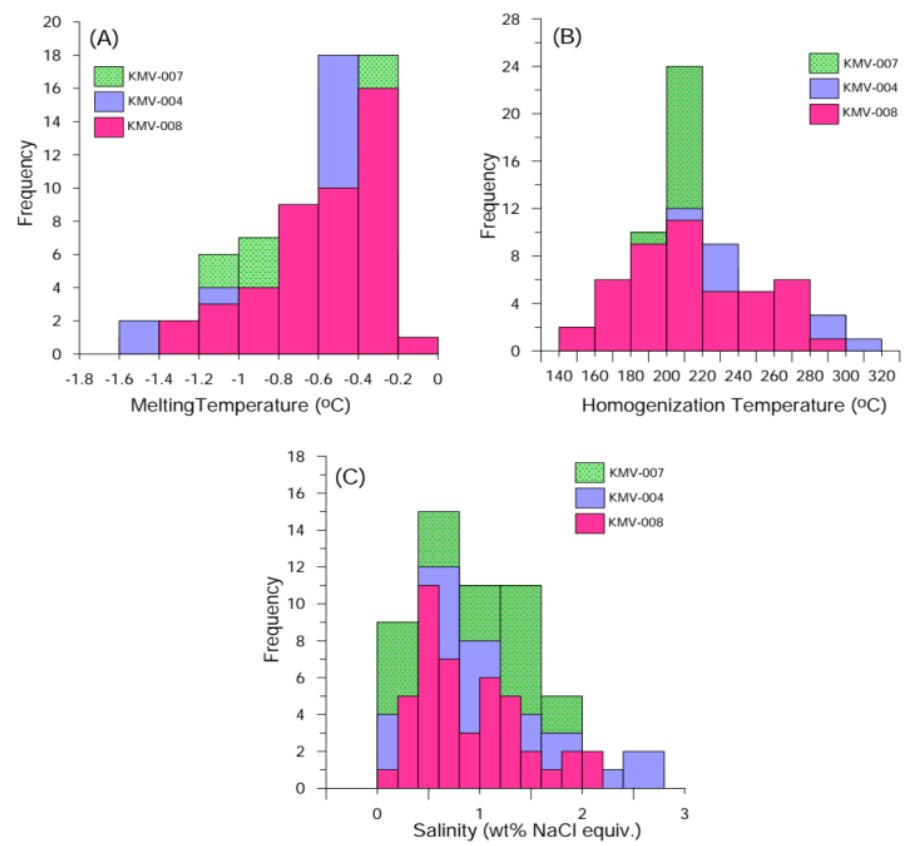

Fig.11. Histograms showing (a) first ice-melting temperatures; (b) total homogenization temperatures and (c) salinities for primary fluid inclusions in mineralized quartz veins of the Kyaukmyet prospect

Plotting the fluid inclusion salinity and homogenization temperature (Th) data on a graph shows the fluid's physiochemical path during the evolution of a hydrothermal system (Wilkinson, 2001). The data of the fluid inclusions from the Kyaukmyet prospect quartz veins are plotted on Fig.12. This graph shows the wide range of Th and salinities and a reference line showing the evolutionary trend for increasing salinity with decreasing temperature. The increasing salinity-decreasing temperature trend is the trend one expects to find in fluid mixing and boiling (Wilkinson, 2001). Subsequently, fluid mixing also could have been occurred by adding or mixing with a more or less saline solutions as a fluid mixing trends is recognized in Fig.13. On the other hand, fluid boiling also cannot be ruled out. Salinities would change during fluid boiling or effervescence in a system and salinity would also be increased during continuous boiling in restricted fractures (Wilkinson, 2001).

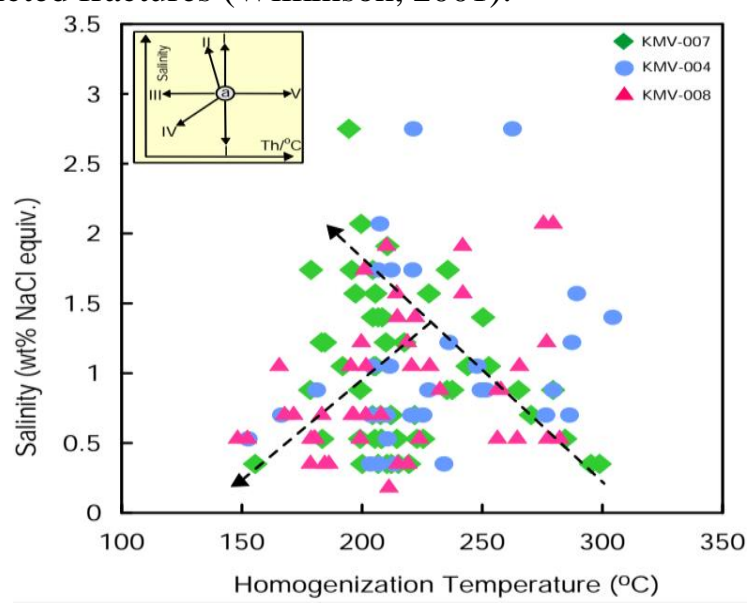

Fig.12. Homogenization temperature $\left(\mathrm{Th}{ }^{\circ} \mathrm{C}\right.$ ) versus salinity (wt.\% $\mathrm{NaCl}$ equiv.) for primary fluid inclusions in three mineralized quartz veins from the Kyaukmyet prospect. The inset schematic diagram illustrating temperature-salinity trends or fluid evolution paths due to different geological processes (modified from Shepherd et al. 1985). (I) isothermal mixing; (II) boiling; (III) simple cooling; (IV) mixing of fluids with different homogenization temperatures and salinities; (V) leakage 


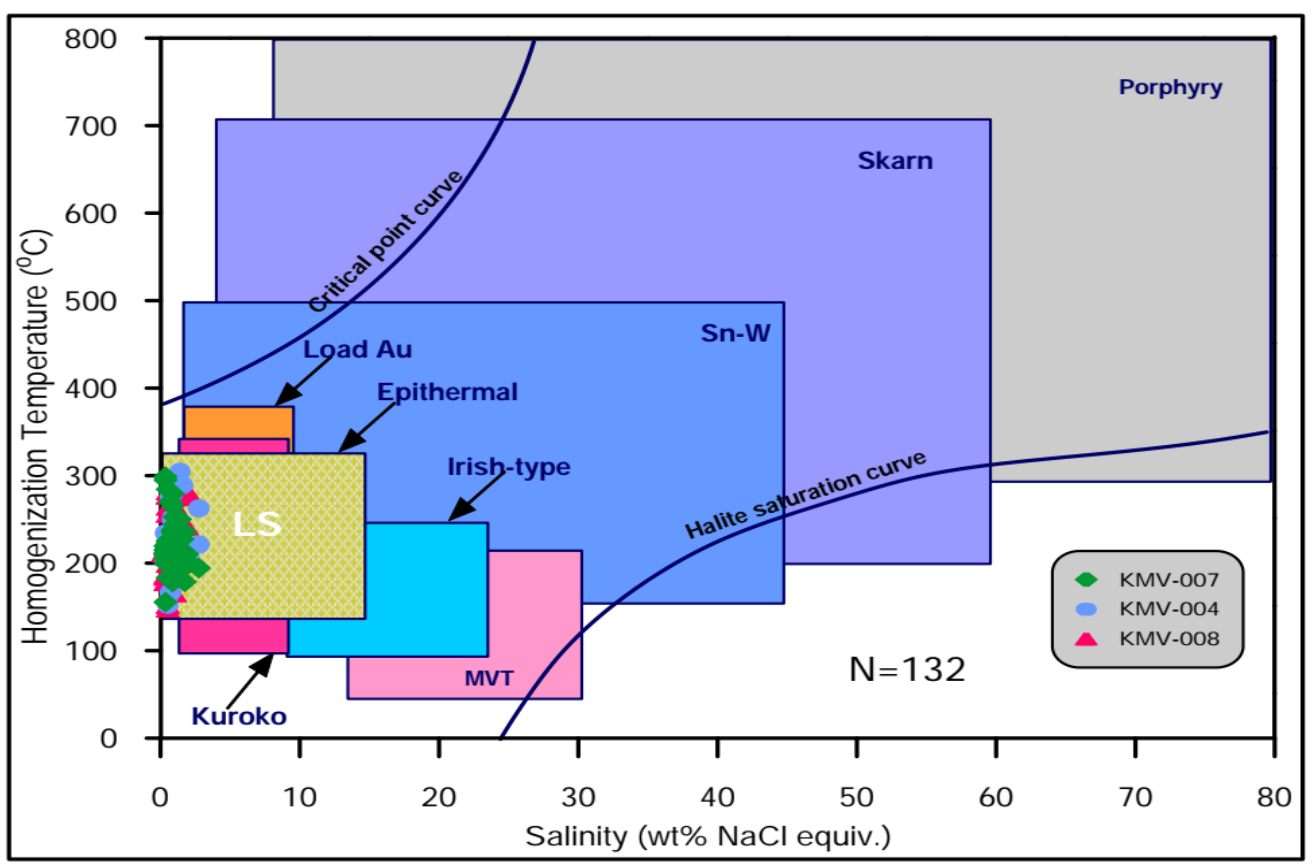

Fig.13. Th $\left({ }^{\circ} \mathrm{C}\right)$ versus salinity diagram (Wilkinson, 2001) plot showing fluid inclusion microthermometric data falls into low sulfidation (LS) epithermal system

\section{Discussion}

\subsection{Ore-Forming Fluid}

Fluid inclusion study plays an important role in constraining the conditions under which the hydrothermal fluids formed and in determining the likely fluid sources (Wilkinson, 2001). In epithermal systems, homogenization temperatures generally range from around $140{ }^{\circ} \mathrm{C}$ to $350{ }^{\circ} \mathrm{C}$ and salinities commonly range from $0 \%$ to $13 \% \mathrm{NaCl}$ equiv. (Roedder, 1984). The homogenization temperature ranges and averages for the three mineralized quartz veins from the Kyaukmyet prospect are $153{ }^{\circ} \mathrm{C}$ to $304{ }^{\circ} \mathrm{C}$ (average Th $228{ }^{\circ} \mathrm{C}$ ) for $\mathrm{KMV}-004,178{ }^{\circ} \mathrm{C}$ to $299{ }^{\circ} \mathrm{C}$ (average Th $238{ }^{\circ} \mathrm{C}$ ) for KMV-007, and $148{ }^{\circ} \mathrm{C}$ to $282{ }^{\circ} \mathrm{C}$ (average Th $238{ }^{\circ} \mathrm{C}$ ) for KMV-008. The salinites of fluid inclusion in quartz range from 0.35 to $2.75 \% \mathrm{NaCl}$ equivalent. The relationships between the homogenization temperature ranges and salinities have been used to distinguish deposit types (Wilkinson, 2001). The Kyaukmyet fluid inclusions have low salinities and low Th. When they are plotted on the (Wilkinson, 2001) temperature-salinity deposit type discrimination diagram, they fall in the low sulfidation epithermal deposit type field Fig.13.

Fluid inclusion studies can reveal the close relationship between homogenization temperatures, salinity, and hydrothermal fluid sources (Shepherd et al. 1985; Wilkinson, 2001). The skarn and porphyry deposits are formed from the magmatic fluids which have salinity more than 5-70 wt $\% \mathrm{NaCl}$ equiv. and most of the meteoric fluids in hydrothermal systems are less than $5 \% \mathrm{NaCl}$ equiv. (Burnham, 1979; Hedenquist and Lowenstern, 1994; Simmons and Brown, 2006). The low salinities of the Kyaukmyet prospect fluids $(0.35 \mathrm{wt} \%-2.75 \mathrm{wt} \% \mathrm{NaCl}$ equiv.) indicate that the fluids that formed the Kyaukmyet epithermal quartz veins were predominantly of meteoric origin with a small amount of magmatic fluid input. Furthermore, previous research has shown that when the fluid inclusions' homogenization temperatures and salinity show a positive correlation, fluid mixing has most likely occurred; however, when those values show a negative correlation, it is also possible that the fluid boiling may have accompanied in the system (Shepherd et al. 1985; Zhai et al. 2009; Zhai et al. 2013). 
The presence of coexisting liquid-rich and vapor-rich inclusions, adularia, colloform, crustiform, and bladed calcite lend support to the boiling of ore fluid during the Kyaukmyet ore forming process. The homogenization temperature and salinity plot also show a trend of fluid mixing Fig.12, suggesting that the mineralization was formed by isothermally mixing of meteoric fluid with minor other fluids. Therefore, it is most likely that fluid mixing and boiling made significant contributions to lower temperature that triggering for gold and base metals precipitation at the Kyaukmyet prospect.

\subsection{Trapping Pressure and Mineralization Depth}

Previous research has shown that low-sulfidation epithermal deposits are commonly emplaced at depths between $100 \mathrm{~m}$ and $1000 \mathrm{~m}$ below the paleowater table (Sillitoe and Hedenquist, 2003; Simmons et al. 2005). This depth corresponds to a hydrostatic pressure of less than $10 \mathrm{MPa}$ (100 bars). Under these low-pressure conditions, the fluid inclusions data can be used to estimate the formation temperature of the mineralizing fluids (Takacs et al., 2017). The formation or trapping temperature of the quartz veins can be estimated from the microthermometric data, especially from Th. Under boiling conditions, this trapping temperature can be considered to be the first peak on a Th histogram (Bodnar et al. 1985). As described above, fluid boiling has been proposed as a part of the formation mechanism for the mineralized quartz veins at the Kyaukmyet prospect.

In addition to the fluid inclusion data, the presence of adularia, lattice bladed calcite, lattice-bladed calcite replaced by quartz, crustiform, banded, colloform, and plumose/feathery textured quartz all suggest that fluid boiling occurred. The texture indicates slowly changing or very mildly fluctuating conditions in the fluid during crystals growth (Fournier, 1985). Observations made during the field investigation suggest that bladed textures and quartz vein textures are closely associated with gold deposition. The lattice bladed texture is an aggregate of platy calcite crystals with numerous interstices suggesting that the texture is likely due to the result of fluid boiling. The presence of both adularia and platy calcite are also indications of fluid boiling. (Simmons and Christenson, 1994) stated that adularia precipitation is caused by the loss of carbon dioxide to the vapor phase during hydrothermal fluid boiling. Boiling also increases the solution's pH. In most cases the mineralized veins at the Kyaukmyet prospect have sharp contacts within their host volcanic and volcaniclastic rocks. These contacts imply that the mineralized quartz veins were generated by open-space filling under hydrostatic pressure (Hedenquist and Arribas, 1998). Therefore, the formation temperatures for the quartz veins are taken directly from first peaks of the homogenization temperature histograms. The three mineralized quartz veins from the Kyaukmyet prospect have yielded peak, 200-220 ${ }^{\circ} \mathrm{C}$. This temperature range is most likely the formation temperatures of three mineralized quartz veins. Moreover, their first peak salinity ranges are also very similar $(0.35 \mathrm{wt} \%-0.75 \mathrm{wt} \% \mathrm{NaCl}$ equiv. $)$ with a mean salinity of $0.5 \mathrm{wt} \% \mathrm{NaCl}$ equiv. The formation temperature estimated from the Th data can be used to estimate the formation depth of the veins. The formation temperatures for the Kyaukmyet quartz veins were plotted on a boiling point curve Fig.14 (Haas, 1971) and the minimum formation depth range is estimated to be $165-256 \mathrm{~m}$ below the paleowater table. This depth is equivalent to hydrostatic pressure of around $1.56 \mathrm{MPa}$ to 2.32 MPa. These paleodepth and pressure estimations for the Kyaukmyet prospect suggest that mineralization took place in a low-sulfidation epithermal system that formed at a depth of 100-1000 m and a pressure below $10 \mathrm{MPa}$ (100 bars). 


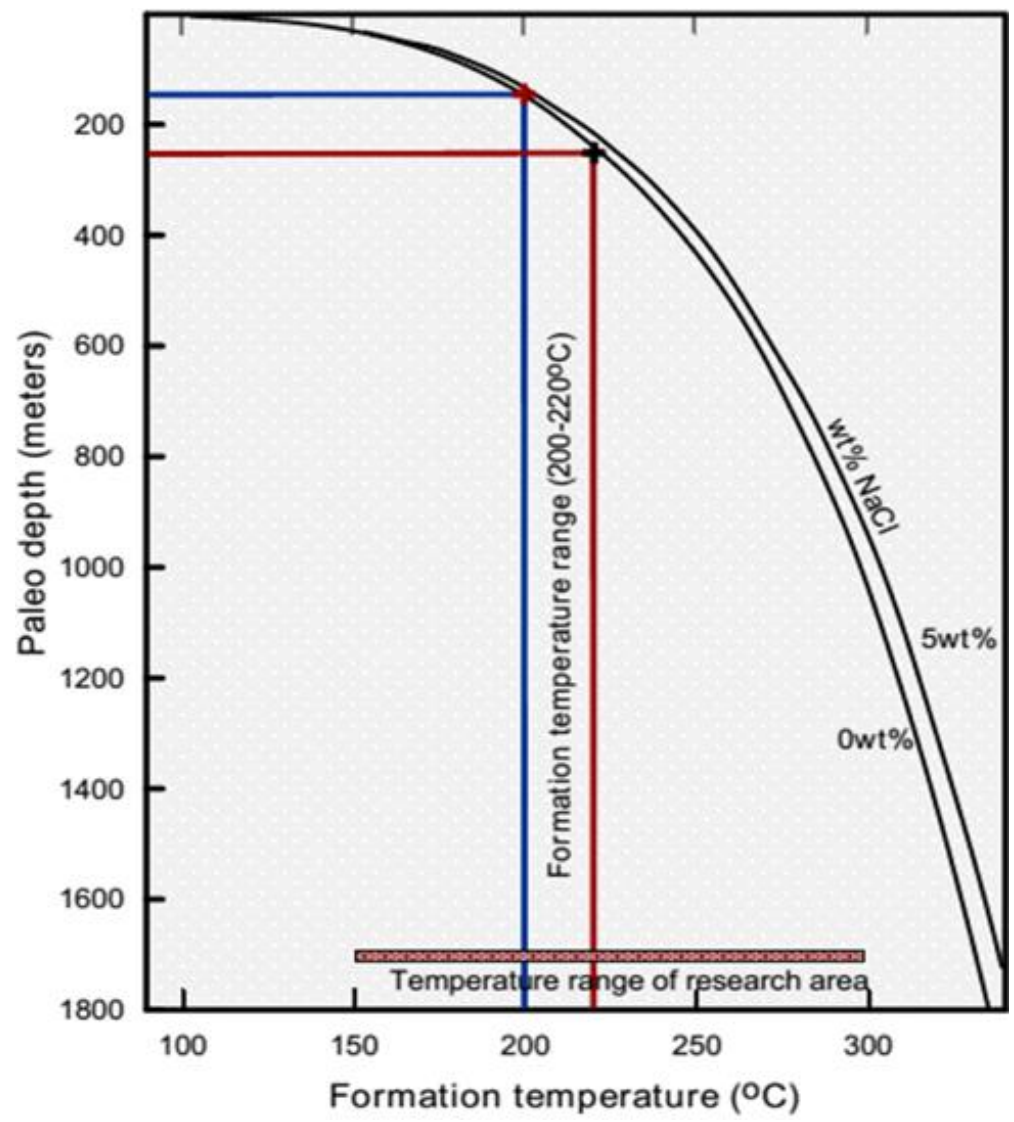

Fig.14. Temperature versus paleo-depth diagram with boiling-point curves of $5 \mathrm{wt} \% \mathrm{NaCl}$ equiv. (Haas, 1971) showing an estimation of average minimum formation depth of mineralized quartz veins from the Kyaukmyet prospect

\section{Conclusions}

The Kyaukmyet prospect area in the Monywa District, Central Myanmar, is underlain mainly by volcanic and volcaniclastic rocks of the Late Oligocene to Middle Miocene Magyigon Formation; the orientation of structures in the area is controlled by regional faults. Ore is present as crustiform textured gold-bearing brecciated quartz veins and banded (colloform) and massive quartz veins. The most common ore mineral assemblages are pyrite + sphalerite + galena + small amount of chalcopyrite and gold. Supergene covellite, hematite, and goethite are also present. The ore is mainly hosted by altered rock consisting of quartz, adularia, illite, illite/smectite, sericite, and calcite produced by silicification and argillic as well as propylitic alteration. Fluid inclusion petrography and microthermometry show that the mineralized quartz veins at Kyaukmyet contain low homogenization temperature (Th) and low salinity fluid inclusions. Most primary fluid inclusions are trapped in quartz crystal growth zones and in isolated planes in the quartz. Two-phase liquid-rich inclusions are much more abundant than two-phase vapor-rich inclusions. The coexistence of the liquid-rich and the vapor-rich fluid inclusions indicate that the hydrothermal fluid was boiling. Fluid inclusion data shows that the ore fluid was formed by the mixing of a considerable amount of meteoric fluid with smaller amounts of magmatic fluid. Sulfide minerals and gold were precipitated when the fluid boiled. The evidence for fluid boiling is provided by the presence of adularia, lattice bladed calcite, lattice-bladed calcite replaced by quartz, and colloform, crustiform, comb, mosaic, and zonal quartz, indicating that fluid boiling was a process that initiated gold and base metals deposition. The existence of a wide range of fluid inclusion homogenization temperatures and salinities supports the fluid boiling hypothesis. 
On a fluid inclusion Th-salinity diagram, the Kyaukmyet prospect fluid inclusions plot in a location comparable to the majority of the ore fluids from epithermal systems studied elsewhere in the world. The estimated formation temperature for the crustiform-textured gold-bearing brecciated quartz veins and banded (colloform) and massive quartz veins at Kyaukmyet is $200-220{ }^{\circ} \mathrm{C}$ and the formation depth beneath the paleo groundwater table is estimated to be between $165 \mathrm{~m}$ and $256 \mathrm{~m}$. Hydrostatic pressures at those depths are approximately $1.56 \mathrm{MPa}$ and $2.32 \mathrm{MPa}$, respectively. On the basis of all the available data including hydrothermal alteration, quartz vein textures, ore mineralogy, and fluid inclusion data, it is concluded that the Kyaukmyet prospect was formed under a polymetallic low-sulfidation epithermal deposit.

\section{Acknowledgements}

The authors want to express our deepest gratitude to AUN/SEED-Net and JICA program for their financial supporting to conduct this research. We are grateful to Kyaw Zin Oo and Then Zaw who help during the field work and local people for their kind helps and permission during the field work. We are grateful to Prof. Dr. Akira Imai and Dr. Kotaro Yonezu as well as laboratory members from the Department of Earth Resource Engineering, Kyushu University, Japan for their supports for laboratory analysis and valuable suggestions on data interpretation. Special thanks are also due to Prof. Dr. Khin Zaw of CODES, University of Tasmania for reading the earlier versions of the manuscript and his valuable suggestions. The authors are greatly indebted to two anonymous reviewers for their constructive and valuable suggestions to improve the manuscript). The authors are very grateful to the Editor in Chief Prof. Dr. Salih M. Awadh, the Secretary of Journal Mr. Samir R. Hijab and the Technical Editors for their great efforts and valuable comments.

\section{References}

Awadh, S. M., Habib, H. R., Al-Bassam, K. S., 2008. Upper Cretaceous carbonate-hosted zinc-lead-barite deposits in Northern Thrust Zone, northern Iraq: Petrography and geochemistry. Arabian Journal Geoscience, 1, 75-85.

Awah, S. M., Neibert, K., 2016. Polymetallic sulfide ores hosted in Late Permian carbonate at the Alanish locality, northern Iraq: petrography and mineral chemistry. Arabian Journal Geoscience, 9, 540

Bodnar, R. J., Reynolds, T. J., Kuehn, C.A., 1985. Fluid inclusion systematics in epithermal systems: Reviews in Economic Geology, 2: 73-97.

Bodnar, R. J., 1993. Revised equation and table for determining the freezing point depression of $\mathrm{H}_{2} \mathrm{O}-\mathrm{NaCl}$ solutions. Geochimica et Cosmochimica Acta, 57 (3), 83-684.

Burnham, C.W., 1979. Chapter 3: magmas and hydrothermal fluids. In: Barnes, H.L. (Ed.), Geochemistry of Hydrothermal Ore Deposits, 2nd edition. John Wiley \& Sons Inc, New York, 71-136.

Chhibber, H. L., 1934. The mineral resources of Burma, London, Macmillan and Co, 320 pp.

Fournier, R. O., 1985. The behavior of silica in hydrothermal solution, In: Berger RP, Bethke PM (eds.) Geology and geochemistry of epithermal systems. Society of Economic Geologists, Chelsea, 45-61.

Haas, J.L., 1971. The effect of salinity on the maximum thermal gradient of a hydrothermal system at hydrostatic pressure. Economic Geology, 66, 940-946.

Hedenquist, J. W., Lowenstern, J. B., 1994. The role of magmas in the formation of hydrothermal ore deposits. Nature, 370, 519-527.

Hedenquist, J.W., Arribas, A., 1998. Evolution of an intrusion-centered hydrothermal system: Far southeast Lepanto porphyry and epithermal $\mathrm{Cu}-\mathrm{Au}$ deposits. Philippines. Economic. Geology, 93, 373-404.

Htet, W.T., 2008. Volcanic-hosted gold-silver mineralization in the Monywa mining district, central Myanmar. Phd. Dissertation, Mandalay University, Myanmar.

Kirwin, D., 1994. Technical assessment of the Monywa porphyry copper district, Mandalay province, Union of Myanmar,1, 2- 3. 
Knight, J., Zaw, K., 2015. The geochemical and geochronological framework of the Monywa high sulfidation Cu and low sulfidation Au-epithermal deposits, Myanmar. Poster No. 104 presented at the SEG, 2015 Conference; 27-30 September, Hobart, Tasmania, Australia.

Mitchell, A. H. G., Myint, W., Lynn, K., Htay, M.T., Oo, M., Zaw, T., 2011. Geology of the High Sulfidation Copper Deposits, Monywa Mine, Myanmar. Resource Geology, 61, 1-29.

Mitchell, A. H. G., Chung, S. L., Oo, T., Lin, T.H., Hung, C.H., 2012. Zircon U-Pb ages in Myanmar: magmatic-metamorphic events and the closure of a neo-Tethys ocean. Journal of Asian Earth Sciences, 56, $1-23$.

Roedder, E., 1984. Fluid Inclusions; Reviews in Mineralogy; Mineralogical Society of America: Chantilly, VA, USA, vol. 12, 646p.

Salem, I. A., Ibrahim, M. E., El Monsef, M., 2010. Mineralogy, geochemistry, and origin of hydrothermal manganese veins at Wadi Maliek, Southern Eastern Desert, Egypt. Arabian Journal of Geosciences, 5 (3), 385-406.

Shepherd, T. J., Rankin, A. H., Alderton, D. H. M., 1985. A Practical Guide to Fluid Inclusion Studies. Blacie \& Son Press, London.

Sillitoe, R. H., Hedenquist, J. W., 2003. Linkages between volcanotectonic settings, ore fluid compositions, and epithermal precious metal deposits. Society of Economic Geologists Special Publication, 10, 315-343.

Simmons, S. F., Christenson, B.W., 1994. Origins of calcite in a boiling geothermal system. American Journal of Science, 294 (3), 361-400.

Simmons, S.F., White, N.C., John, D.A., 2005. Geological characteristics of epithermal precious and base metal deposits. Economic Geology, $485-522$.

Simmons, S. F., Brown, K. L., 2006. Gold in magmatic hydrothermal solutions and the rapid formation of a Giant ore deposit, Science, 314, 288-291.

Takács, A., Molnar, F., Turi, J., Mogessie, A., Menzies, J.C., 2017. Ore mineralogy and fluid inclusion constraints on the temporal and spatial evolution of a high-sulfidation epithermal $\mathrm{Cu}-\mathrm{Au}-\mathrm{Ag}$ deposit in the recsk ore complex, Hungary. Economic Geology, 112, 1461-148.

Wilkinson, J. J., 2001. Fluid inclusions in hydrothermal ore deposits. Lithos, 55, 229-272.

Win, K., Kirwin, D., 1998. Exploration, geology and mineralization of the Monywa copper deposits, Central Myanmar, In: Porphyry and Hydrothermal Copper and Gold Deposits: A Global Perspective. Proceedings of the Australian Mineral Foundation Conference, Perth, 61-74.

Zaw, K., 1989. Comments on transcurrent movements in the Myanmar-Andaman sea region. Geology, 17, 93-95.

Zaw, K., 1990. Geological, petrological and geochemical characteristics of granitoid rocks in Burma: with special reference to the associated W-Sn mineralization and their tectonic setting. Journal of Southeast Asian Earth Sciences, 4, 293-335.

Zaw, K., 2017. Chapter 24 Overview of mineralization styles and tectonic-metallogenic setting in Myanmar. Geological Society, London, 48, 531-556.

Zaw, K., Swe, M., Myint, T.A., Knight, J., 2017. Copper deposits of Myanmar. Geology, Resources and Tectonics, 48, 573-588.

Zhai, W., Sun, X., Sun, W., Su, L., He, X., Wu, Y., 2009. Geology, geochemistry, and genesis of Axi: a Paleozoic low-sulfidation type epithermal gold deposit in Xinjiang, China. Ore Geology Reviews, 36 (4), 265-281.

Zhai, D.G., Liu, J. J., Wang, J. P., Yao, M. J., Wu, S.H., Fu, C., Liu, Z.J., Wang, S.G., Li, Y.X., 2013. Fluid evolution of the Jiawula $\mathrm{Ag}-\mathrm{Pb}-\mathrm{Zn}$ deposit, Inner Mongolia: mineralogical, fluid inclusion, and stable isotopic evidence. International Geology Reviews, 55 (2), 204-224. 